\title{
Changes in the firn structure of the western Greenland Ice Sheet caused by recent warming
}

\author{
S. de la Peña ${ }^{1}$, I. M. Howat ${ }^{2}$, P. W. Nienow ${ }^{3}$, M. R. van den Broeke ${ }^{4}$, E. Mosley-Thompson ${ }^{1}$, S. F. Price ${ }^{5}$, D. Mair ${ }^{6}$, \\ B. Noël ${ }^{4}$, and A. J. Sole ${ }^{7}$ \\ ${ }^{1}$ Byrd Polar and Climate Center, The Ohio State University, Scott Hall, 1090 Carmack Road, Columbus, OH 43212, USA \\ ${ }^{2}$ School of Earth Sciences, The Ohio State University, 125 South Oval Mall, Columbus, OH 43210-1002, USA \\ ${ }^{3}$ School of GeoSciences, The University of Edinburgh, Geography Building, Drummond Street, Edinburgh EH8 9XP, UK \\ ${ }^{4}$ Institute for Marine and Atmospheric research Utrecht (IMAU), Utrecht University, P.O. Box 80000, \\ 3508 TA Utrecht, the Netherlands \\ ${ }^{5}$ Fluid Dynamics Group, Los Alamos National Laboratory, T-3, Mail Stop B216, Los Alamos, NM 87545, USA \\ ${ }^{6}$ The College of Physical Sciences, University of Aberdeen, Fraser Noble Building, King's College, Aberdeen, \\ AB24 3UE, UK \\ ${ }^{7}$ Department of Geography, The University of Sheffield, Sheffield, S10 2TN, UK
}

Correspondence to: S. de la Peña (santiagodpr@gmail.com)

Received: 15 January 2015 - Published in The Cryosphere Discuss.: 27 January 2015

Revised: 1 May 2015 - Accepted: 11 May 2015 - Published: 11 June 2015

\begin{abstract}
Atmospheric warming over the Greenland Ice Sheet during the last 2 decades has increased the amount of surface meltwater production, resulting in the migration of melt and percolation regimes to higher altitudes and an increase in the amount of ice content from refrozen meltwater found in the firn above the superimposed ice zone. Here we present field and airborne radar observations of buried ice layers within the near-surface $(0-20 \mathrm{~m})$ firn in western Greenland, obtained from campaigns between 1998 and 2014. We find a sharp increase in firn-ice content in the form of thick widespread layers in the percolation zone, which decreases the capacity of the firn to store meltwater. The estimated total annual ice content retained in the near-surface firn in areas with positive surface mass balance west of the ice divide in Greenland reached a maximum of $74 \pm 25 \mathrm{Gt}$ in 2012, compared to the 1958-1999 average of $13 \pm 2 \mathrm{Gt}$, while the percolation zone area more than doubled between 2003 and 2012. Increased melt and column densification resulted in surface lowering averaging $-0.80 \pm 0.39 \mathrm{~m} \mathrm{yr}^{-1}$ between 1800 and $2800 \mathrm{~m}$ in the accumulation zone of western Greenland. Since 2007, modeled annual melt and refreezing rates in the percolation zone at elevations below $2100 \mathrm{~m}$ surpass the annual snowfall from the previous year, implying that mass gain in the region is retained after melt in the form
\end{abstract}

of refrozen meltwater. If current melt trends over high elevation regions continue, subsequent changes in firn structure will have implications for the hydrology of the ice sheet and related abrupt seasonal densification could become increasingly significant for altimetry-derived ice sheet mass balance estimates.

\section{Introduction}

Investigations in the percolation zone of the Greenland Ice Sheet (GrIS) have revealed a highly variable snowpack structure characterized by the presence of ice lenses, pipes, and layers (Benson, 1962; Scott et al., 2006a; Parry et al., 2007; Harper et al., 2012). The heterogeneous snowpack characteristic of this region results from periods of relatively high snow accumulation followed by short melt events during summer. During melt episodes, surface meltwater percolates through the snowpack and may refreeze at depth. The atmosphere has warmed considerably in the last decade over the GrIS (van den Broeke et al., 2009; Box et al., 2012; Bennartz et al., 2013), with 2010 and 2012 being the warmest years in western Greenland since records began (Tedesco et al., 2011, 2013; Bennartz et al., 2013; Tingley and Huybers, 2013). As 
a consequence, the area of the ice sheet covered by percolation facies has grown, and the amount of surface melt and subsequently refrozen meltwater retained in the firn has increased (Tedesco et al., 2008; Fettweis et al., 2011; Harper et al., 2012, Fettweis et al., 2013; van Angelen et al., 2014). Extreme warming events such as in July 2012 (Nghiem et al., 2012; Bennartz et al., 2013) have further intensified melt, but it is unknown whether increasing meltwater production and subsequent percolation and refreezing at high elevations has shifted the equilibrium line higher and affected the buffering and transport of meltwater over the interior of the ice sheet. Furthermore, these processes and their high spatial and temporal variability have implications for altimetry-derived mass balance estimates.

A model-based study by Pfeffer et al. (1991) showed that predictions of runoff-induced sea level rise from Greenland that did not consider meltwater refreezing within the firn could be overestimating sea level rise by as much as $5 \mathrm{~cm}$ over the next 150 years. The importance of meltwater retention was further highlighted by a study (Harper et al., 2012) based on field measurements obtained in 2007, 2008 and 2009 along the Expédition Glaciologique Internationale au Groenland (EGIG) line in western Greenland. Harper et al. (2012) estimated that Greenland's firn has the potential to store between 322 and $1289 \mathrm{Gt}$ of meltwater, confirming its importance as a buffer between surface melt and runoff. Firn-ice content was greater than $50 \%$ by volume at altitudes below $1600 \mathrm{~m}$, decreasing steadily with elevation. At the time, the presence of ice at an elevation of $2000 \mathrm{~m}$ was found to be relatively uncommon. That work added to a series of studies conducted between 2003 and 2006 as part of the first CryoSat Validation Experiment that helped assess near-surface snowpack and firn conditions at the higher end of the percolation zone (1950-2350 m). The CryoSat validation work focused on the region's spatially variable stratigraphy, as characterized by the presence of thin ice layers that were the main source of backscatter of Ku-band altimeter signals (Scott et al., 2006a; Parry et al., 2007; Helm et al., 2007). Together, these studies can provide a decadal record of ice content and can be linked with earlier data from the National Aeronautics and Space Administration (NASA) Program for Arctic Regional Climate Assessment (PARCA, Abdalati et al., 1998). In the late 1990s, PARCA collected scores of shallow firn and ice cores to quantify spatial and temporal variability of annual accumulation rates over the GrIS (e.g. McConnell et al., 2000; Bales et al., 2001; Mosley-Thompson et al., 2001).

Here, we use snowpit data and airborne radar and laser remote sensing observations from the percolation zone of western Greenland in conjunction with output from regional climate model of melt, runoff, and snow accumulation to (a) quantify changes in percolation conditions after the unusually warm years of 2010 and 2012; (b) identify areas where widespread ice layers formed by meltwater percolation and refreezing are found; and (c) assess the state and

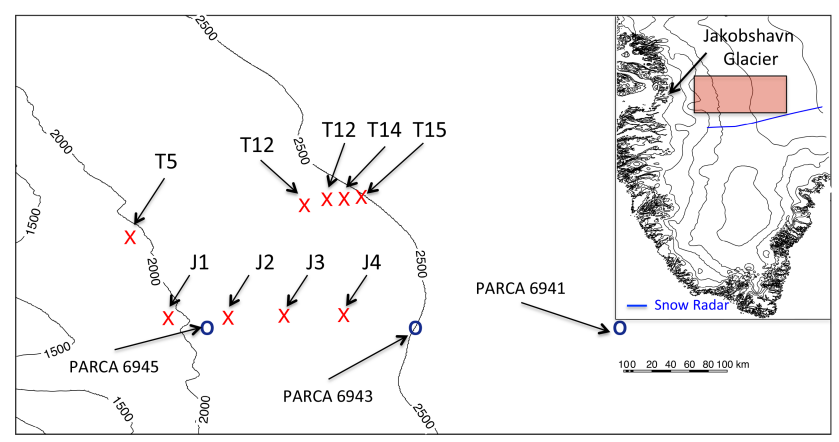

Figure 1. Location of research area and research sites (all T-sites are along the EGIG line). Inset: map of western Greenland showing the area surveyed. Blue line is the flight path of the NASA Operation IceBridge data shown in Figs. 4 and 5. Snowpit sites are shown with an $\mathrm{X}$, while core sites are shown with a blue circle. Contour lines represent $500 \mathrm{~m}$ surface elevation intervals.

extent of the percolation zone of the GrIS given current melt trends over the ice sheet interior. For this, we estimated the total ice content and area covered by percolation facies resulting from melting and refreezing patterns across a wide elevation range on the western slope of the GrIS. Our field sites are all located within one degree of latitude $\left(69.2^{\circ} \mathrm{N}-\right.$ $71.1^{\circ} \mathrm{N}$ ) on the western slope of the ice sheet, spanning an elevation range from 1900 to $2500 \mathrm{~m}$ (Fig. 1). At each site, snowpits were excavated in April of 2011, 2012, 2013 and 2014 in order to characterize regional near-surface $(\sim 2-$ $3 \mathrm{~m})$ snowpack conditions and percolation facies in the region following the melt season from the previous year. Extensive melt layers were identified and traced using airborne radar to identify areas covered by percolation facies, and airborne laser altimetry data were used to estimate annual elevation changes in the region. Additionally, output from the Regional Atmospheric Climate Model (RACMO2.3/GR, van Meijgaard et al., 2008; Ettema et al., 2009; van den Broeke et al., 2009) are used to assess, at a regional scale, the intensity and extent of the abnormally strong 2010 and 2012 melt seasons in Greenland's accumulation zone that led to the sharp increase in the observed firn-ice content.

\section{Methods and observations}

We measured firn ice content by measuring ice layer thickness in snow pits made during April (pre-summer melt) field campaigns between 2011 and 2014. The 2011 campaign was part of CryoSat-2 validation activities continuing efforts initiated in 2004 and 2006 (Parry et al., 2007; Scott et al., 2006a, b; Helm et al., 2007). Near-surface density and stratigraphy measurements were obtained from snow pits at four sites in the upper end of the percolation zone, located between 2350 and $2490 \mathrm{~m}$ along the EGIG line (named T12-T15 hereafter for historical reasons). The April 2012, 2013 and 2014 campaigns were part of a study of outlet glacier dynamics and 
also included snow pit surveys of winter accumulation and ice layer thickness at four sites in the catchment of Jakobshavn Glacier (hereafter referred as J1-J4 sites) between elevations of 1935 and $2350 \mathrm{~m}$ (Fig. 1). Additionally, we extended the firn-ice content record in this area back in time to 1977 using three shallow firn cores drilled in 1998 at 2000, 2500 , and $2795 \mathrm{~m}$ elevation $\left(69^{\circ} \mathrm{N}, 45^{\circ} \mathrm{W} ; 69^{\circ} \mathrm{N}, 43^{\circ} \mathrm{W}\right.$; and $69^{\circ} \mathrm{N}, 41^{\circ} \mathrm{W}$ ) as part of PARCA. The cores were dated using a combination of the winter minima in the seasonal variations of dust concentration, $\delta^{18} \mathrm{O}$, and $\mathrm{H}_{2} \mathrm{O}_{2}$ (MosleyThompson et al., 2001). Although the thickness of each annual layer (after being converted to water equivalent using density) can be ascertained using any one of these parameters, for this study the layer thicknesses (net accumulation) were calculated using the winter minima in dust concentration.

We used remote sensing observations acquired by NASA's Operation IceBridge Snow Radar and the Airborne Topographic Mapper (ATM). The Snow Radar is a wideband radar that operates in the $2-6.5 \mathrm{GHz}$ frequency range and can map polar firn internal layers with a range resolution of $\sim 5 \mathrm{~cm}$ (Panzer et al., 2013; Leuschen et al., 2014), and is used to trace the ice layers beneath the winter accumulation in 2011 by identifying internal radar reflections caused by melt layers. The ATM is a scanning laser altimeter used in this study to estimate annual elevation change between 2010 and 2013 along a frequently repeated transect in western Greenland (Fig. 1).

Output data from the RACMO2.3/GR model with a horizontal resolution of $\sim 11 \mathrm{~km}$ (Ettema et al., 2009; van den Broeke et al., 2009) are used in combination with the remote sensing observations to map the percolation zone extent. For the GrIS, RACMO2.3/GR is coupled with a physical multilayer snow model that treats surface albedo as a function of melt as well as percolation and refreezing (Bougamont et al., 2005; Van Angelen et al., 2014). A recent study comparing RACMO2.3/GR results with melt rates derived from the Scanning Multichannel Microwave Radiometer (SMMR) mission shows that discrepancies between the model and satellite data occur mainly in areas of high meltwater runoff (Fettweis et al., 2011), due in part to the lack of remote sensing capability of assessing melt and runoff rates. There is good agreement at higher elevations, which suggests that assumptions about snowpack heat transfer and energy balance in the model are well parameterized for the percolation zone of the GrIS. Thus, the model results used here are limited to regions with no simulated meltwater runoff. The logic for the estimates for total ice content derived from the model results is as follows: at the lower elevations of this no-runoff area where modeled melt exceeds total accumulation, with total firn ice content water equivalent values close to total accumulation. At higher elevations, total firn ice content measured in the field and presented in Sect. 3 of this paper represents a percentage of the total modeled melt. This percentage of the modeled melt in the form of observed firn-ice decreases

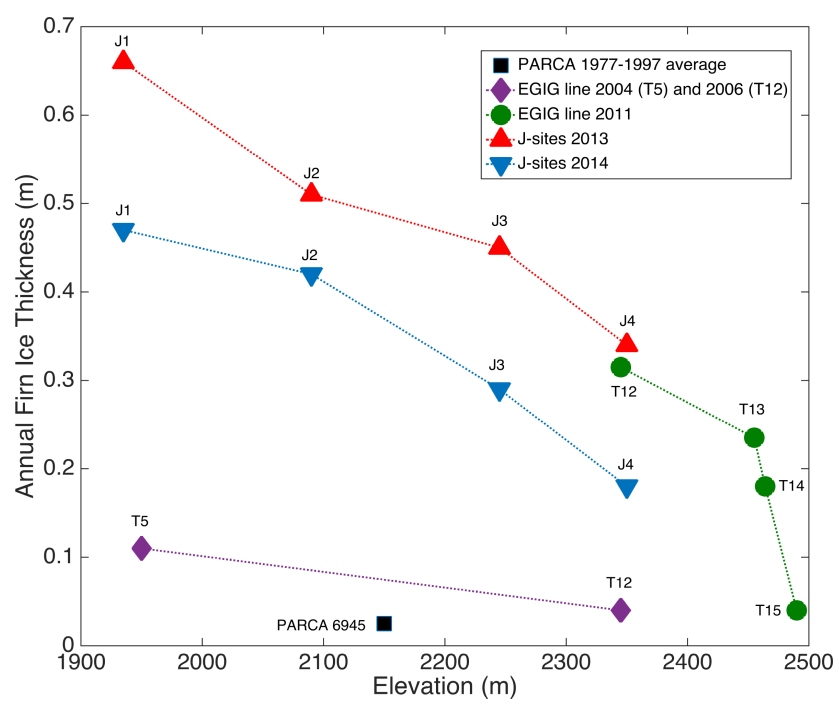

Figure 2. Firn ice content vs. elevation measured in field campaigns between 1998 and 2014. All measurements taken from snow pits except the PARCA 1977-1997 average taken from core 6945.

with elevation. This is the main cause of the relatively large uncertainty in the estimates of the total refrozen meltwater presented in Sect. 4.

\section{Snowpack structure}

Figure 2a illustrates the ice layers and lenses present in each PARCA core's visible stratigraphy. Cores 6945 and 6943 (named for the coordinates where they were acquired) are $\sim 18 \mathrm{~m}$ long and extend back to 1976 while core 6941 is $11.7 \mathrm{~m}$ long and extends to a depth equating to 1985 's accumulation. The thickness of the different annual layers is affected by annual snowfall, deflation and redeposition by wind, compaction, and melting, and varies on the order of tens of $\mathrm{cm}$ from year to year in western Greenland (McConnell et al., 2000; de la Peña et al., 2010; Burgess et al., 2010). Small amounts of ice are commonly found in the core, but are not present on an annual basis. While no ice was observed in core 6945 over the periods of 1977-1979 and 1996-1997, between 1987 and 1991 several thin ice layers were found separated by a few $\mathrm{cm}$. Most layers were found to be 3-4 cm thick, and the thickest (1989) was $9 \mathrm{~cm}$ thick. Cores 6943 and 6941 show similar patterns, with occasional ice layers $1-2 \mathrm{~cm}$ thick.

Current conditions are represented in the schematic (Fig. 2b), made from measurements of winter snow depth and ice layer thickness for each site visited during spring in 2013 and 2014 and illustrating the near-surface stratigraphy as found in spring 2014. Ice content measured in 2011 at $\mathrm{T} 12$, a site located at the same altitude as $\mathrm{J} 4$ but roughly $10 \mathrm{~km}$ north is included as well. The stratigraphy of the shallow firn cores shows that at least between 1977 and 1997, 


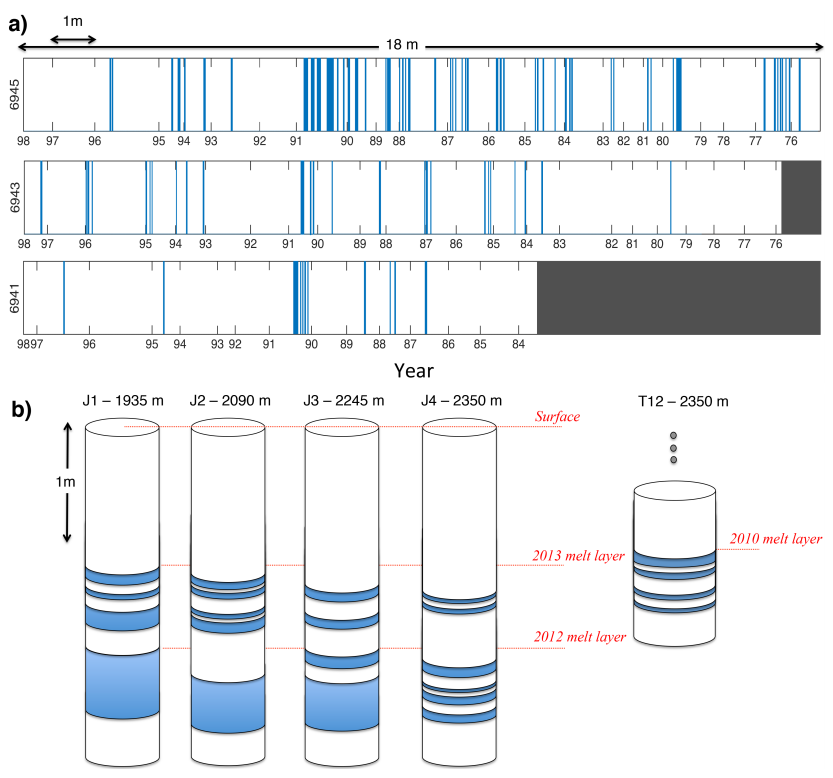

Figure 3. (a) Ice layers and ice lenses present in the visible stratigraphy of PARCA firn cores 6941, 6943, and 6945 drilled in 1998 are plotted with depth in core $(\mathrm{m})$. The deepest core is $18 \mathrm{~m}$ long and the dates are assigned at depth (m) of each year's winter minima in dust concentration. (b) Schematic showing ice layer structure as measured in snow pits excavated between 2011 and 2014. The melt layer dashed lines indicate the position where the top of the ice layer was found in the field at $\mathrm{J} 1$ for the $\mathrm{J}$-sites and at T12. J-sites are represented as found in April 2012. T12 representation is shown as found in 2011.

melt events at higher elevations were rarer and much less intensive relative to those observed since. The extreme melt events of 2012 created conditions that facilitated the formation of impermeable ice layers several times thicker than previously observed across this elevation in the percolation zone of the GrIS. These layers were found at all sites visited and appear to be continuous throughout the area surveyed. In 2004, total ice thickness at an elevation of $1950 \mathrm{~m}$ averaged $10 \mathrm{~cm}$ (Parry et al., 2007), significantly less than the ice content in 2013 at $\mathrm{J} 4$, located $400 \mathrm{~m}$ higher on the ice sheet. The total mass of the ice layers found at the $\mathbf{J}$ sites averaged $441 \pm 12 \mathrm{~kg} \mathrm{~m}^{-2}(0.48 \pm 0.013 \mathrm{~m}$ thick $)$ and $306 \pm 118 \mathrm{~kg} \mathrm{~m}^{-2}(0.33 \pm 0.128 \mathrm{~m}$ thick) in 2013 (related to 2012 melt season) and 2014 (related to 2013 melt season) respectively. In April 2011 at the higher elevation sites, the total ice layer mass was 285,255 and $160 \mathrm{~kg} \mathrm{~m}^{-2}$ for $\mathrm{T} 12, \mathrm{~T} 13$ and T14 respectively. Ice content decreased at T15 $(h=2490 \mathrm{~m})$, where an ice layer just $4 \mathrm{~cm}$ thick $\left(36 \mathrm{~kg} \mathrm{~m}^{-2}\right)$ was found, suggesting this site was close to the boundary of the dry snow zone that year. At the J-sites, winter accumulation was measured at $1.11 \pm 0.17 \mathrm{~m}, 0.885 \pm 0.08 \mathrm{~m}$, and $1.35 \pm 0.07 \mathrm{~m}$ in the winters of 2011-2012, 2012-2013 and 2013-2014 respectively. The 2010-2011 winter accumulation measured at the T12-T15 sites was $1.10 \pm 0.12 \mathrm{~m}$. Win- ter snow density was measured in 2011 and exhibited little variability $\left(247 \pm 8 \mathrm{~kg} \mathrm{~m}^{-3}\right)$, consistent with previous observations (Parry et al., 2007). Total annual ice content found beneath the wintertime snow accumulation during each of the campaigns described in the previous section is summarized in Fig. 3, revealing the sharp increase in firn-ice content since 2010, where the annual ice layers were an order of magnitude thicker in total than the 1977-1997 average from PARCA core 6945.

Measurements in April 2011 by the NASA Snow Radar show the extent of the type of percolation features as described above that formed during the 2010 melt season (Fig. 4). Data for the years 2012 and 2013 are not available. The $\sim 420 \mathrm{~km}$-long transect extends from the ablation zone to the ice divide in the dry snow zone and overflights close to our research sites. Radar signals are partially backscattered from within a stratified snowpack by abrupt changes encountered in snow density and/or ice structure, such as ice layers in the percolation zone, or "autumn hoar" in the dry snow zone. Near surface layering is observed in the 1600$2200 \mathrm{~m}$ elevation range and winter accumulation over the previous summer melt layer is clearly resolved while deeper layers are obscured by infiltration ice that limits radar signal penetration. The topmost reflection under the observed winter surface is continuous over most of the percolation zone, confirming that ice layers observed at the $\mathrm{J}$ field sites are widespread over an elevation range of 1600 to $2200 \mathrm{~m}$, about $220 \mathrm{~km}$ inland from the ice margin. The ice layer was retraced with a custom-made threshold algorithm configured to identify strong reflections underneath the surface (shown with a black line in Fig. 4). The retracker was applied up to $2450 \mathrm{~m}$, an elevation at which isochrones can be observed to a depth greater than $5 \mathrm{~m}$, evidence that no significant amount of ice is present in the snowpack to prevent radar signal penetration. The threshold algorithm tracks continuity between horizontally adjacent pixels, so that the retraced layer in one individual radar acquisition is not separated vertically by more than $\sim 20 \mathrm{~cm}$ from the next measurement. In some sections the buried signal could not be differentiated from the surface, and at some points there is discontinuity in the signal. However, for most of the percolation zone the reflection appears continuous, tracked at a depth of $0.81 \pm 0.29 \mathrm{~m}$, slightly lower than the field measurements at $\mathrm{T}$ sites. The underestimation is likely the result of tracking on the leading edge of the signal and does not affect our analysis.

At higher elevations, annual accumulation layers are clearly seen at depths of at least $15 \mathrm{~m}$, consistent with previous observations from the dry snow zone (Hawley et al., 2006; de la Peña et al., 2010; Simonsen et al., 2013). While melt has intensified over the last decade, the 2012 melt episodes had notably bigger impacts on the firn structure, with significant melting and infiltration extending to the ice divide (Tedesco et al., 2013). Figure 5 shows annual elevation changes over the same transect shown in Fig. 4 obtained from repeat ATM lidar overflights between 


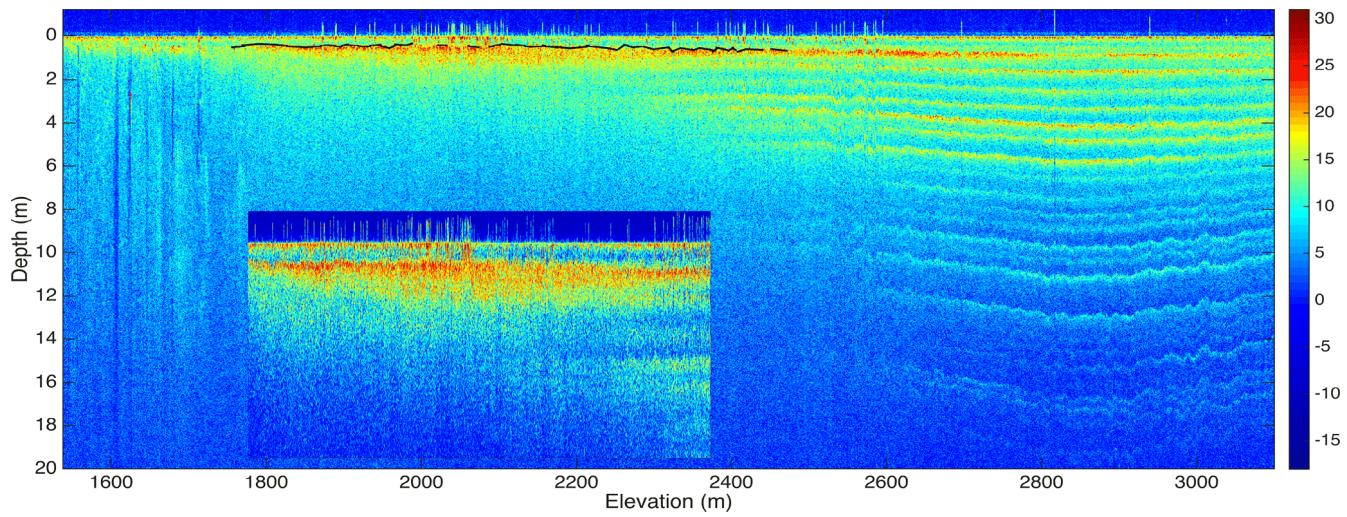

Figure 4. A transect in western Greenland showing Operation IceBridge Snow Radar response to the snowpack in 2011. The aerial survey extends (left to right) from the ablation zone to the dry snow zone. The color scale shows the relative power intensity (in $\mathrm{dB}$ ). The black line shows the position where the melt layer (i.e. the top of the ice layer formed after the 2010 melt season) was retraced. Inset shows the upper $\sim 5 \mathrm{~m}$ where the melt layer is located.

2010 and 2013. While snow accumulation variability and ice dynamics are factors in the observed surface elevation change, lowering of the magnitude observed in 2012-2013 must be the result of surface melt, infiltration and densification of the firn, since variability in annual snow accumulation is not large enough to cause the departure seen in 2012-2013, and there is no indication that dynamic thinning during that year was significantly different from previous years. Average elevation change estimated across the 1600$2600 \mathrm{~m}$ elevation range is $-0.803 \pm 0.391 \mathrm{~m} \mathrm{yr}^{-1}$, compared to $-0.112 \pm 0.067 \mathrm{~m} \mathrm{yr}^{-1}$ and $0.031 \pm 0.188 \mathrm{~m} \mathrm{yr}^{-1}$ in 2010-2011 and 2011-2012 respectively. This difference does not represent a loss in mass but rather a rapid densification of the near-surface structure of the firn, with surface lowering observed almost at the ice divide.

\section{Melt intensity and extent of the percolation zone}

Figure 6 presents results from RACMO2.3/GR between 1958 and 2013 for each of the sites visited between 2011 and 2014, and Table 1 shows modeled melt and accumulation rates for the years 2003, 2010, and 2012. Melt at J1 increased from $340 \mathrm{~kg} \mathrm{~m}^{-2}$ in 2003 to $810 \mathrm{~kg} \mathrm{~m}^{-2}$ in 2012 (3 times the 1958-1999 average of $285 \mathrm{~kg} \mathrm{~m}^{-2}$ ), but as discussed in the previous section, total ice content increased more than 5 times over the same period. Ice layer thickness does not increase as a simple function of surface melt. Infiltration of meltwater into firn is complicated by factors including the initial thermal state and structure of the firn and the timing and duration of melt. For example, more frequent extreme melt events, such as the event that occurred in 2012, may cause rapid snow saturation and refreezing near the surface, resulting in the formation of thicker and more extensive ice layers. The formation of ice reservoirs of this magnitude is thus not only dependent on melt increase, but also on

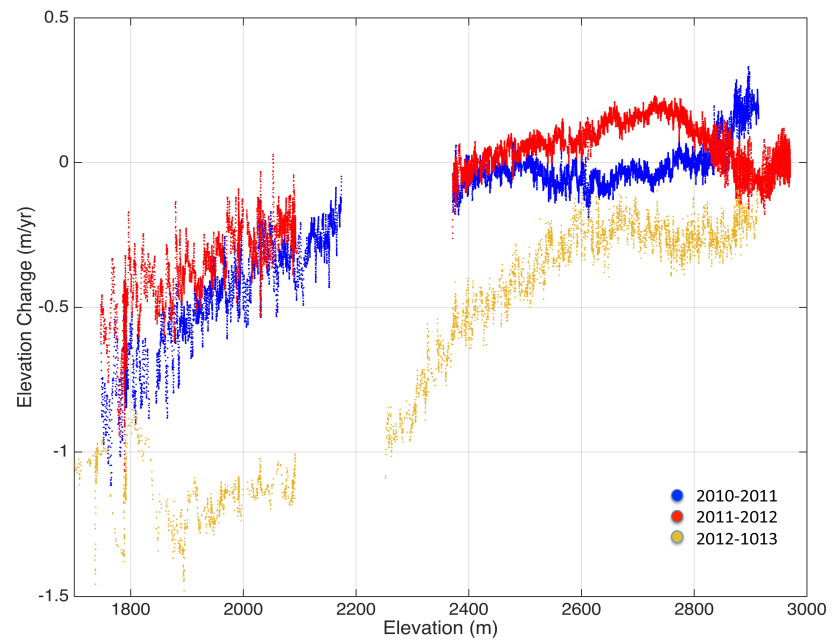

Figure 5. Elevation change estimated from NASA ATM laser altimeter in western Greenland along the flight path shown in Fig. 1. Estimates are for annual change in 2011 (blue), 2012 (red), and 2013 (yellow).

how melt is distributed during summer. Uncertainties in melt and refreezing rates in RACMO2.3/GR add to this complexity, and as a result, it is difficult to confidently predict firn changes using only the model results. For instance, in 2003, the ice layers observed to have formed during the summer at $2000 \mathrm{~m}$ elevation accounted for $29 \%$ of the total modeled melt, while in 2012 discernible ice content was $79 \%$ of the modeled melt $(52 \%$ at the highest site at $2350 \mathrm{~m})$. The 2012 melt season anomaly was driven partly by extreme, shortlived melt episodes (i.e. Nghiem et al., 2012; Bennartz et al., 2013; Tedesco et al., 2013), which as discussed may result in more ice content. Increases in modeled melt rates at higher sites are even more pronounced than at $\mathrm{J} 1$, with rates at $\mathrm{J} 4$ increasing from less than $100 \mathrm{~kg} \mathrm{~m}^{-2}$ over the period from 
Table 1. Melt and accumulation at each field site as simulated by RACMO2.3/GR.

\begin{tabular}{lrrrrr}
\hline Site & Latitude & Longitude & $\begin{array}{r}\text { Elevation } \\
(\mathrm{m})\end{array}$ & $\begin{array}{r}\text { Melt }\left(\mathrm{kg} \mathrm{m}^{-2}\right) \\
2003 / 2010 / 2012\end{array}$ & $\begin{array}{r}\text { Accumulation }\left(\mathrm{kg} \mathrm{m}^{-2}\right) \\
2003 / 2010 / 2012\end{array}$ \\
\hline $\mathrm{J} 1$ & $69.212^{\circ} \mathrm{N}$ & $46.152^{\circ} \mathrm{W}$ & 1935 & $340 / 753 / 808$ & $520 / 497 / 648$ \\
$\mathrm{~J} 2$ & $69218^{\circ} \mathrm{N}$ & $45.566^{\circ} \mathrm{W}$ & 2090 & $250 / 569 / 729$ & $513 / 644 / 500$ \\
$\mathrm{~J} 3$ & $69.221^{\circ} \mathrm{N}$ & $44.762^{\circ} \mathrm{W}$ & 2245 & $87 / 341 / 637$ & $505 / 492 / 635$ \\
$\mathrm{~J} 4$ & $69.221^{\circ} \mathrm{N}$ & $44.089^{\circ} \mathrm{W}$ & 2350 & $31 / 305 / 580$ & $505 / 480 / 628$ \\
$\mathrm{~T} 12$ & $70.175^{\circ} \mathrm{N}$ & $45.345^{\circ} \mathrm{W}$ & 2345 & $37 / 195 / 502$ & $498 / 548 / 599$ \\
$\mathrm{~T} 13$ & $70.274^{\circ} \mathrm{N}$ & $45.008^{\circ} \mathrm{W}$ & 2455 & $17 / 178 / 507$ & $501 / 550 / 604$ \\
$\mathrm{~T} 14$ & $70.302^{\circ} \mathrm{N}$ & $44.757^{\circ} \mathrm{W}$ & 2464 & $17 / 170 / 455$ & $496 / 546 / 601$ \\
$\mathrm{~T} 15$ & $70.302^{\circ} \mathrm{N}$ & $44.574^{\circ} \mathrm{W}$ & 2490 & $13 / 104 / 399$ & $493 / 538 / 601$ \\
\hline
\end{tabular}

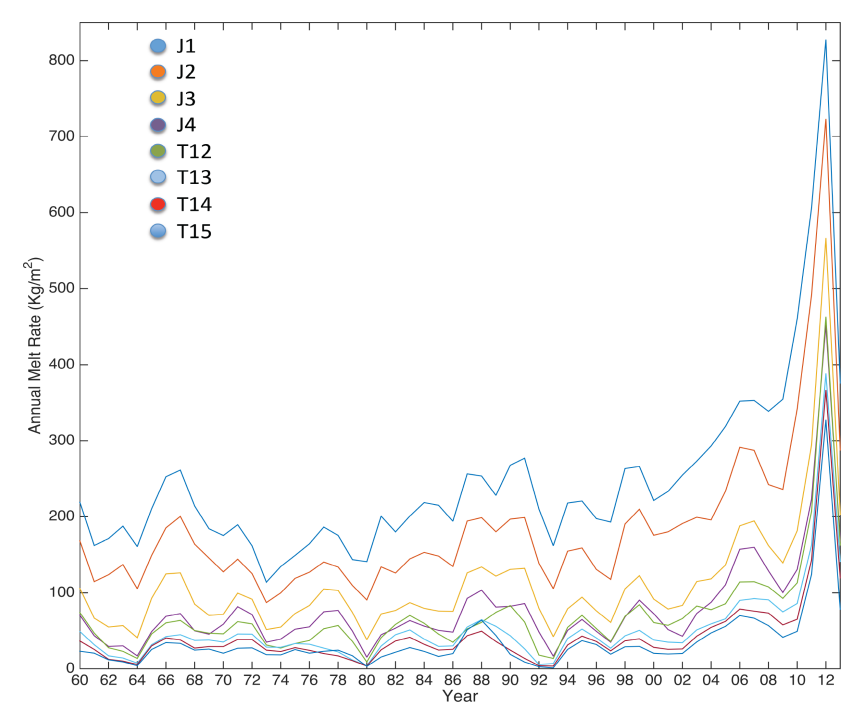

Figure 6. 1958-2013 modeled annual melt rates from RACMO2.3/GR for each field site visited between 2011 and 2014.

1958 to 1999 , to a rate of 305 and $580 \mathrm{~kg} \mathrm{~m}^{-2}$ in 2010 and 2012 respectively (Fig. 6). Prior to 2012, the largest modeled melt rates occurred in 2010 at all sites except at the highest regions (above $2200 \mathrm{~m}$ ), which registered the largest melt rate in 2007 (second highest for the lower sites). Large modeled melt rates at all sites occurred during the warm years of 1995, 1998, 2007 and 2010. Melt at J1 increased from less than $300 \mathrm{~kg} \mathrm{~m}^{-2}$ between 1958 and 1999 , to $340 \mathrm{~kg} \mathrm{~m}^{-2}$ in 2003 and to $755 \mathrm{~kg} \mathrm{~m}^{-2}$ in 2010 . At J4 there was only an increase of $30 \%$ in 2010 with respect to 2003 (from 235 to $305 \mathrm{~kg} \mathrm{~m}^{-2}$ ), but this increased to $580 \mathrm{~kg} \mathrm{~m}^{-2}$ in 2012 . Before 2012, the modeled melt rate at this site was highest in 2007, in contrast to the 2010 peak melt rates estimated for most of the western Greenland margin (Tedesco et al., 2011). The mass of ice found in 2013 at sites J1 and J2 exceeds the mass of the total annual accumulation for 2012, a trend that according to RACMO2.3/GR has been occurring at J1 since 2007. Modeled melt rates in 2013 are significantly lower than in 2012, but still larger than the 1958-1999 av- erage. We found no evidence of meltwater pathways or pond formation at our field sites. If, however, conditions for impermeable ice layers keep forming over extensive areas and melt continues to exceed total accumulation, it is likely that lateral supraglacial transport and eventual runoff of excess meltwater will reach a $2000 \mathrm{~m}$ elevation in western Greenland.

Figure 7 presents annual melt predicted by RACMO2.3/GR in areas of the GrIS with predicted positive surface mass balance (i.e. the accumulation zone) for each time period presented. The left figure shows the 1958-1999 average, while the right figure shows the annual melt rates in 2012, illustrating the changes in melt intensity and the size of the areas affected by melt over Greenland. The predicted average area of the accumulation zone that experienced melt between 1958 and 1999 was about $405000 \mathrm{~km}^{2}$. The extent of this area then increased $240 \%$ in 10 years, from $465000 \mathrm{~km}^{2}$ in 2003 to a maximum of $1155000 \mathrm{~km}^{2}$ in 2012, more than half the total area of the ice sheet. Although in 2010 the percolation zone covered a total area of $486000 \mathrm{~km}^{2}$, only a $5 \%$ increase with respect to 2003 , the intensity of melt increased drastically after 1999 , especially in west and southwest Greenland. To quantify the magnitude of refrozen meltwater in 2012, we estimate total annual ice content in western Greenland by identifying areas where snowfall and melt rates are sufficiently high (greater than $100 \mathrm{~kg} \mathrm{~m}^{-2}$ per year) to form the stratified snowpack structure described above. We estimate the total mass refrozen in the snowpack in western Greenland by relating melt rates from RACMO2.3/GR to the measured ice content found during 2011 and 2013, and subtract the mass of the snow that occupied the volume where meltwater refroze (total ice content cannot exceed the total winter accumulation). Based on the field measurements, we assume an average winter snow density of $250 \mathrm{~kg} \mathrm{~m}^{-3}$. Our estimates indicate that the total 2012 infiltration ice content above the equilibrium line and west of the ice divide of the GrIS was $74 \pm 25 \mathrm{Gt}$, compared to an average of only $13 \pm 2 \mathrm{Gt}$ between 1958 and 1999. Most of this ice is distributed near the surface solely in the form of thick layers that appear to be widespread. 


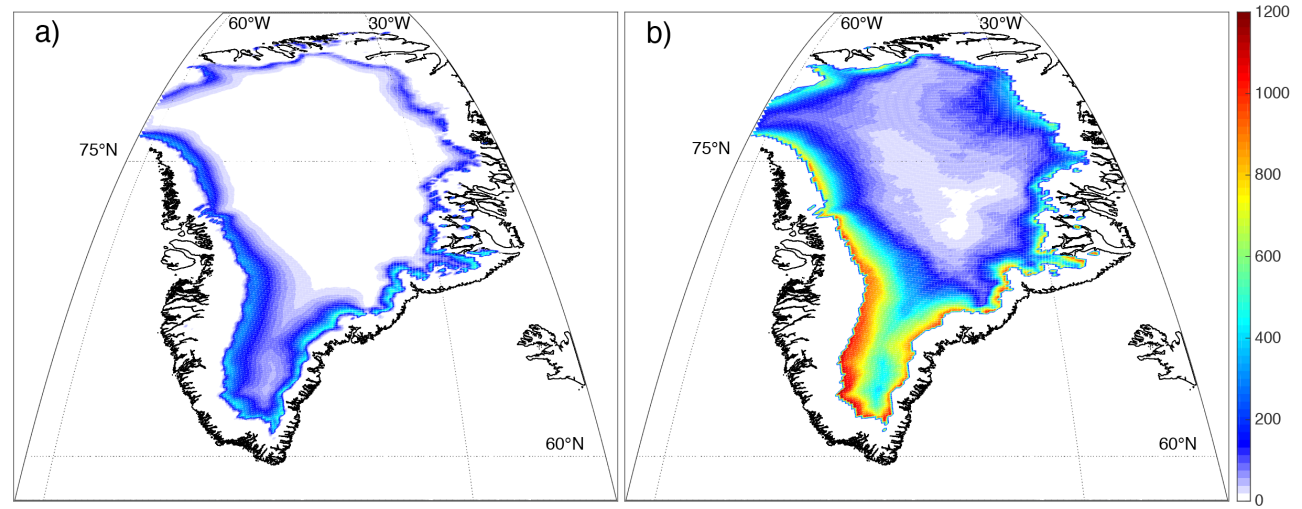

Figure 7. Regional Atmospheric Climate Model (RACMO2.3/GR) annual melt rates $\left(\mathrm{kg} \mathrm{m}^{-2}\right)$ shown for areas of the GrIS with predicted positive surface mass balance (i.e. above the equilibrium line). Annual melt rates shown for (a) the 1958-1999 average and (b) for 2012.

\section{Discussion and conclusions}

Our field observations reveal substantial, recent changes in the structure of high-elevation percolation facies that differ from those recorded in previous decades. Observations in 2004 and 2006 showed an increase from the 1977-1997 average ice content, but the lack of significant ice above $2000 \mathrm{~m}$ was evidence that the transition between the percolation and dry snow zones was near this elevation (Scott et al., 2006b). In contrast, the Snow Radar data obtained in spring 2011 reveal that the percolation zone has risen with the transition in the previous few years occurring at elevations between 2200 and $2400 \mathrm{~m}$. More importantly, the concentration of ice at higher elevations has increased dramatically, and the formation of thick, widespread continuous ice layers is increasingly common over extensive areas of the percolation zone causing large changes in the air content of the firn. Furthermore, the increase in firn ice content raises questions regarding the permeability of the firn column across the percolation zone, and the effects it could have on meltwater retention and transport and on firn compaction rates.

The formation of percolation facies in the last few decades of the 20th century above $2000 \mathrm{~m}$ was limited, and during some years melt was not even strong enough to form identifiable ice layers. In this context, the percolation features described here have no recent precedent. Considering, as measured in the field, an average surface snow density before melt of $250 \mathrm{~kg} \mathrm{~m}^{-3}$, and that meltwater refreezes in a volume occupied by snow of this density, each meter of winter snow would equate to layers of ice totaling $\sim 0.35 \mathrm{~m}$ thick after refreezing if little or no air remains trapped within. This process will create the observed seasonal change in the volume of the firn governed by accumulation, compaction, and melting and refreezing. Even without thermal snow densification, commonly used steady-state snow density and firn compaction assumptions used for altimetry-derived mass balance estimates would need to be reconsidered for regions where percolation features become more impermeable. These ice layers not only significantly limit the total meltwater buffering capacity of the percolation zone estimated by Harper et al. (2012), but also introduce variability in compaction rates if air is trapped within ice layers. Moreover, and as observed at sites $\mathrm{J} 1$ and $\mathrm{J} 2$, the winter snow in these regions of the accumulation zone of the ice sheet completely melted and refroze in 2012, meaning mass gain in these areas was in the form of superimposed ice. Although the melt season of 2012 was unusually warm, rather than an isolated episode it represent the most dramatic example of changes that are occurring due to the above-average warming in western Greenland observed in the last decade.

Melt affecting the GrIS has increased over recent decades, with pronounced departures from the 1958-1999 mean melt rate during the last few years in regions well within the accumulation zone of the GrIS. High (and highly variable) accumulation rates play an important role in the surface mass balance of the ice sheet at higher elevations, but with melt rates increasing faster than snow accumulation in Greenland (Fettweis, 2007; Van Angelen et al., 2014), meltwater excess during warm years may saturate the already limited firn meltwater storage capacity over large areas (Van Angelen et al., 2013). Although no evidence of extensive lateral hydrological pathways was found at any of our field sites, it is likely that if melt continues to exceed total accumulation, water will soon be transported to lower elevations by supraglacial flow, especially during years experiencing extreme melt. Recent studies show that lakes are increasingly found at higher elevations (Banwell et al., 2012; Liang et al., 2012; Howat et al., 2013), and it is unclear how the percolation zone will evolve if more meltwater ponds are being formed over firn. Furthermore, according to RACMO2.3, if current warming trends continue, the percolation zone will potentially extend to most areas above the equilibrium line. Regardless of the role they will play in the future, these huge ice reservoirs are the result of an intense melting process of the same order of magnitude as the total mass imbalance of the GrIS, and the consequences of their formation described here underlines 
the importance of monitoring the evolution of Greenland's firn layer in the coming years.

Acknowledgements. The authors thank the reviewers for their insightful comments. We thank the staff of CH2MHill Polar Services and the crew of Norlandair for their consistently excellent field support, and we thank John Pailthorpe for his help during the 2011 field campaign. This work was funded by grants NNX13AP92G and NNX11AR47G from the U.S. National Aeronautics and Space Administration, and by grant NER/O/S/2003/00620 from the U.K. Natural Environment Research Council.

Edited by: E. Larour

\section{References}

Abdalati, W., Bales, R., and Thomas, R.: Program for Arctic Regional Climate Assessment. An improved understanding of the Greenland ice sheet, Arct. Res., 12, 38-54, 1988.

Bales, R. C., McConnell, J. R., Mosley-Thompson, E., and Csatho, B.: Accumulation over the Greenland Ice Sheet from historical and recent records, J. Geophys. Res., 106, 33813-33825, doi:10.1029/2001JD900153, 2001.

Banwell, A. F., Arnold, N. S., Willis, I. C., Tedesco, M., and Ahlstrøm, A. P.: Modeling supraglacial water routing and lake filling on the Greenland Ice Sheet, J. Geophys. Res.-Earth Surf., 117, F04012, doi:10.1029/2012JF002393, 2012.

Bennartz, R., Shupe, M. D., Turner, D. D., Walden, V. P., Steffen, K., Cox, C. J., Kulie, M. S., Miller, N. B., and Pettersen, C.: July 2012 Greenland melt extent enhanced by low-level liquid clouds, Nature, 496, 83-86, doi:10.1038/nature12002, 2013.

Benson, C.: Stratigraphic studies of the snow and firn of the Greenland ice sheet, Res. Rep., 70, U.S. Army Snow Ice and Permafrost Res. Estab, 1962.

Bougamont, M., Bamber, J. L., and Greuell, W.: A surface mass balance model for the Greenland Ice Sheet, J. Geophys. Res., 110, F04018, doi:10.1029/2005JF000348, 2005.

Box, J. E., Fettweis, X., Stroeve, J. C., Tedesco, M., Hall, D. K., and Steffen, K.: Greenland ice sheet albedo feedback: thermodynamics and atmospheric drivers, The Cryosphere, 6, 821-839, doi:10.5194/tc-6-821-2012, 2012.

Burgess, E. W., Forster, R. R., Box, J. E., Mosley-Thompson, E., Bromwich, D. H., Bales, R. C., and Smith, L. C.: A spatially calibrated model of annual accumulation rate on the Greenland ice sheet annual (1958-2007), J. Geophys. Res., 115, F02004, doi:10.1029/2009JF001293, 2010.

de la Peña, S., Nienow, P., Shepherd, A., Helm, V., Mair, D., Hanna, E., Huybrechts, P., Guo, Q., Cullen, R., and Wingham, D.: Spatially extensive estimates of annual accumulation in the dry snow zone of the Greenland Ice Sheet determined from radar altimetry, The Cryosphere, 4, 467-474, doi:10.5194/tc-4-467-2010, 2010.

Ettema, J., van den Broeke, M. R., van Meijgaard, E., van de Berg, W. J., Bamber, J. L., Box, J. E., and Bales, R. C.: Higher surface mass balance of the Greenland ice sheet revealed by highresolution climate modeling, Geophys. Res. Lett., 36, L12501, doi:10.1029/2009GL038110, 2009.
Fettweis, X.: Reconstruction of the 1979-2006 Greenland ice sheet surface mass balance using the regional climate model MAR, The Cryosphere, 1, 21-40, doi:10.5194/tc-1-21-2007, 2007.

Fettweis, X., Tedesco, M., van den Broeke, M., and Ettema, J.: Melting trends over the Greenland ice sheet (1958-2009) from spaceborne microwave data and regional climate models, The Cryosphere, 5, 359-375, doi:10.5194/tc-5-359-2011, 2011.

Fettweis, X., Hanna, E., Lang, C., Belleflamme, A., Erpicum, M., and Gallée, H.: Brief communication "Important role of the midtropospheric atmospheric circulation in the recent surface melt increase over the Greenland ice sheet", The Cryosphere, 7, 241248, doi:10.5194/tc-7-241-2013, 2013.

Harper, J., Humphrey, N., Pfeffer, W. T., Brown, J., and Fettweis, X.: Greenland ice-sheet contribution to sea-level rise buffered by meltwater storage in firn, Nature, 491, 240-243, doi:10.1038/nature11566, 2012.

Hawley, R. L., Morris, E. M., Cullen, R., Nixdorf, U., Shepherd, A., and Wingham, D. J.: ASIRAS airborne radar resolves internal annual layers in the dry-snow of Greenland", Geophys. Res. Lett., 33, L04502, doi:10.1029/2005GL025147, 2006.

Helm, V., Rack, W., Cullen, R., Nienow, P., Mair, D., Parry, V., and Wingham, D. J.: Winter accumulation in the percolation zone of Greenland measured by airborne radar altimeter, Geophys. Res. Lett., 34, L06501, doi:10.1029/2006GL029185, 2007.

Howat, I. M., de la Peña, S., van Angelen, J. H., Lenaerts, J. T. M., and van den Broeke, M. R.: Brief Communication "Expansion of meltwater lakes on the Greenland Ice Sheet", The Cryosphere, 7, 201-204, doi:10.5194/tc-7-201-2013, 2013.

Leuschen, C., Gogineni, P., Hale, R., Paden, J., Rodríguez, F., Panzer, B., and Gomez, D.: IceBridge Snow Radar L1B geolocated radar echo strength profiles, version 2 [20110419, 20130405]. Boulder, Colorado USA: NASA DAAC at the National Snow and Ice Data Center, 2014.

Liang, Y. L., Colgan, W., Lv, Q., Steffen, K., Abdalati, W., Stroeve, J., Gallaher, D., and Bayou, N.: A decadal investigation of supraglacial lakes in West Greenland using a fully automatic detection and tracking algorithm, Remote Sens. Environ., 123, 127-138, 2012.

McConnell, J. R., Mosley-Thompson, E., Bromwich, D. H., Bales, R. C., and Kyne, J. D.: Interannual variations of snow accumulation on the Greenland Ice Sheet (1985-1996): new observations versus model predictions, J. Geophys. Res., 105, 4039-4046, 2000.

Mosley-Thompson, E., McConnell, J. R., Bales, R. C., Li, Z., Lin, P. N., Steffen, K., Thompson, L. G., Edwards, R., and Bathke, D.: Local to regional-scale variability of annual net accumulation on the Greenland Ice Sheet from PARCA cores, J. Geophys. Res., 106, 33839-33851, doi:10.1029/2001JD900067, 2001.

Nghiem, S. V., Hall, D. K., Mote, T. L., Tedesco, M., Albert, M. R., Keegan, K., Shuman, C. A., DiGirolamo, N. E., and Neumann, G.: The extreme melt across the Greenland ice sheet in 2012, Geophys. Res. Lett., 39, L20502, doi:10.1029/2012GL053611, 2012.

Panzer, B., Gomez-Garcia, D., Leuschen, C., Paden, J., Rodriguez Morales, F., Patel, A., Markus, T., Holt, B., and Gogineni, P.: An ultra-wideband, microwave radar for measuring snow thickness on sea ice and mapping near-surface internal layers in polar firn, J. Glaciol., 59, 244-254, doi:10.3189/2013JoG12J128, 2013. 
Parry, V., Nienow, P., Mair, D., Scott, J., Hubbard, B., Steffen, K., Wingham, D.: Investigations of meltwater refreezing and density variations in the snowpack and firn within the percolation zone of the Greenland ice sheet, Ann. Glaciol., 46, 61-68, 2007.

Pfeffer, W. T., Meier, M. F., and Illangasekare, T. H.: Retention of Greenland Runoff by Refreezing: Implications for Projected Future Sea Level Change, J. Geophys. Res., 96, 22117-22124, 1991.

Scott, J., Mair, D., Nienow, P., Parry, V., and Morris, E.: A groundbased radar backscatter investigation in the percolation zone of the Greenland Ice Sheet, Remote Sens. Environ., 104, 361-373, 2006a.

Scott, J., Nienow, P., Mair, D., Parry, V., Morris, E., and Wingham, D. J.: Importance of seasonal and annual layers in controlling backscatter to radar altimeters across the percolation zone of an ice sheet, Geophys. Res. Lett., 33, L24502, doi:10.1029/2006GL027974, 2006b.

Simonsen, S. B., Stenseng, L., Adalgeirsdottir, G., Fausto, R. S., Hvidberg, C. S., and Lucas-Picher, P.: Assessing a multilayered dynamic firn-compaction model for Greenland with ASIRAS radar measurements, J. Glaciol., 59, 545-558, doi:10.3189/2013JoG12J158, 2013.

Tedesco, M., Serreze, M., and Fettweis, X.: Diagnosing the extreme surface melt event over southwestern Greenland in 2007, The Cryosphere, 2, 159-166, doi:10.5194/tc-2-159-2008, 2008.

Tedesco, M., Fettweis, X., Van den Broeke, M. R., Van de Wal, R. S. W., Smeets, C. J. P. P., Van de Berg, W. J., Serreze, M. C., and Box, J. E.: The role of albedo and accumulation in the 2010 melting record in Greenland, Environ. Res. Lett., 6, 014005, doi:10.1088/1748-9326/6/1/014005, 2011.
Tedesco, M., Fettweis, X., Mote, T., Wahr, J., Alexander, P., Box, J. E., and Wouters, B.: Evidence and analysis of 2012 Greenland records from spaceborne observations, a regional climate model and reanalysis data, The Cryosphere, 7, 615-630, doi:10.5194/tc7-615-2013, 2013.

Tingley, M. P. and Huybers, P.: Recent temperature extremes at high northern latitudes unprecedented in the past 600 years, Nature, 496, 201-205, doi:10.1038/nature11969, 2013.

Van den Broeke, M., Bamber, J., Ettema, J., Rignot, E., Schrama, E., Van de Berg, W. J., van Meijgaard, E., Velicogna, I., and Wouters, B.: Partitioning Recent Greenland Mass Loss, Science, 326, 984 986, doi:10.1126/science.1178176, 2009.

Van Meijgaard, E., van Ulkft, L. H., van de Berg, W. J., Bosveld, F. C.,M. van den Hurí, B. J. J., Lenderink, G., and Siebesma, A. P.:The KNMI regional atmospheric climate model, version 2.1, KNMI Tech. Rep. 302, R. Neth. Meteorol. Inst., De Bilt, Netherlands, 2008.

Van Angelen, J. H., Lenaerts, J. T. M., van den Broeke, M. R., Fettweis, X., and van Meijgaard, E.: Rapid loss of firn pore space accelerates 21 st century Greenland mass loss, Geophys. Res. Lett., 40, 2109-2113, doi:10.1002/grl.50490, 2013.

Van Angelen, J. H., van den Broeke, M. R., Wouters, B., and Lenaerts, J. T. M.: Contemporary (1960-2012) evolution of the climate and surface mass balance of the Greenland ice sheet, Surv. Geophys., 35, 1-20, doi:10.1007/s10712-013-9261z, 2014 